\title{
The nature of addiction and drug rehabilitation
}

Phaedon Kaloterakis

From $1^{\text {st }}$ International Congress on Neurobiology and Clinical Psychopharmacology and European Psychiatric Association Conference on Treatment Guidance

Thessaloniki, Greece. 19-22 November 2009

The current bibliography suggests that drug rehabilitation schemes that are based on psychological and social parameters are efficient. While most researchers consider dependency to substances as symptomatic, there is a lot of controversy concerning the nature and - consequently - the definition of addiction.

The presentation will try to discuss the various points of view, taking into consideration the most recent research in the fields of mental and social health, neuroscience and therapeutic practice.

Published: 22 April 2010

doi:10.1186/1744-859X-9-S1-S15

Cite this article as: Kaloterakis: The nature of addiction and drug

rehabilitation. Annals of General Psychiatry 2010 9(Suppl 1):S15.

- Convenient online submission

- Thorough peer review

- No space constraints or color figure charges

- Immediate publication on acceptance

- Inclusion in PubMed, CAS, Scopus and Google Scholar

- Research which is freely available for redistribution 